DOI: 10.2478 /ausfm-2020-0001

\title{
Travel Down Memory Lane: Nostalgia and Nostophobia in Youth (2017)
}

\author{
Ying Zhu \\ The City University of New York (United States of America) \\ Hong Kong Baptist University (People's Republic of China) \\ E-mail: yingzhu@hkbu.edu.hk
}

\begin{abstract}
The article analyses Youth, a Chinese melodrama directed by Feng Xiaogang in 2017, as a representation of China during a transitional period in history. It explores issues of nostalgia and nostophobia in connection with the complexities of memory, representation, and viewing pleasure. It discusses how sound and image trigger memories and conflicting emotional reactions. In the film's nostalgic and elegiac re-enactment of a controversial past, the military art troupe performs songs and dances extolling socialist virtues as their own lives gradually unravel with the dawn of a post-socialist era. The article elaborates on how Youth reflects and enlivens personal and collective social memory as well as how we negotiate our ambivalent feelings towards the representation of a controversial past.
\end{abstract}

Keywords: Chinese cinema, Feng Xiaogang, Youth, nostalgia, nostophobia.

\section{Introduction}

My article addresses issues of nostalgia and nostophobia as they pertain to the filmic representation of China during the transitional period from socialism to postsocialism. I use a 2017 Chinese feature film Youth (Feng Xiaogang), a sweeping coming-of-age melodrama set during the 1970s-1990s about the transformation of a Maoist military art and culture troupe to address the relationship between (a) popular films depicting a challenging past and (b) viewers' collective memories as well as viewing pleasure. In the film, the young military art troupe members perform songs and dances that extoll "red hearts and iron wills" as their own lives gradually unravel with the dawn of a post-socialist era (Jenkins 2017). The film's exuberant camerawork captures colourful costumes, revolutionary choreography and chorines familiar to a generation of youth coming of age during China's Cultural Revolution. Its doting portrayal of youth innocence and beauty during the first half of the film 
is punctuated in the second half by a graphically brutal depiction of the 1979 SinoVietnamese War that shattered the lives of the two main characters. As the movie takes us further into the free-market era, the male lead - an exemplary collectivist admired for his altruism - is seen to be outdated and cast aside in an increasingly mercenary China. I will examine how Youth reflects and enlivens personal and collective social memory as well as how we negotiate our ambivalent feelings as we react to the filmic representation of a murky past. I will also discuss how sound and image function at the most primal level by triggering mixed memories and conflicting emotions as they capture a culture in transition. A few crucial moments in the film will be singled out to encapsulate the story and the aura of the film and to elaborate on the paradox of memory and viewing pleasure that are simultaneously nostalgic and nostophobic, when the longing for a bygone era is mixed with the fear of that era.

The concept of nostalgia is a term coined by the Swiss physician Johannes Hofer in 1688 by combining the Greek words nostos, meaning "return home" and algia, meaning "longing” or "pain" (Anspach 1934). To Hofer, nostalgia was a medical condition with a simple cure: return to one's homeland. Nostophobia is the antithesis of nostalgia, the fear of returning to a past and a place. My focus here is more on the temporal dimension of the concepts rather than their original connection to space and location. As I analyse reactions to the film, I will incorporate autoethnography, a self-reflective form of analysis to explore my own visceral and corporeal reactions to the film, particularly its soundtrack, while recognizing that younger audiences have a different connection to the film and that their memories of the past are virtual, the result of the transference of the memory of their parents' generation. Though the implanted memories are not part of their repository of experiences (Hirsch 1997), many of the young college-age Chinese viewers I spoke to register mourning and melancholia as part of their emotional journey encountering the film.

\section{Youth as a Story: The Image}

Youth depicts a group of young performers in a military art troupe who sing and dance to the revolutionary tunes of a socialist China against the seismic social and political upheavals in China in the 1970s-80s, from the death of Mao in September 1976, to the subsequent overthrow of the Gang of Four, ${ }^{1}$ and the ascent of the

1 Led by Jiang Qing, Mao Zedong's last wife, the Gang of Four was a political faction composed of four Chinese Communist Party officials who came to prominence during the Cultural Revolution (1966-1976) and were later officially blamed by the Chinese government for the worst excesses of the societal chaos that ensued during the ten years of turmoil. Their downfall on October 6, 1976, a mere month after Mao's death, marked the end of a turbulent political era in China. 
reform-minded Deng Xiaoping. The film largely eschews major political events to focus instead on the change of life at the personal level of these young performers, including the fashionable outfits and hair styles they are drawn to and the Taiwanese and Hong Kong pop music they yearn for, none of which would have been allowed or available during the Mao era, when army uniforms and revolutionary songs were the only options. It is a film about ordinary youth who happen to live through extraordinary times. The film's two main characters are Liu Feng, a goodnatured male dancer compelled to put the wellbeing of others above his own, like an altruistic Communist solider should do, and He Xiaoping, a new female recruit whose provincial demeanour is ridiculed by the more sophisticated performers from more privileged social backgrounds [Fig. 1]. Liu is teasingly nicknamed "Lei Feng Reincarnation" that compares him to Lei Feng (1940-1962), a model PLA soldier in the 1950s known for his altruistic spirit and deeds, and for his devotion to the socialist cause. Lei has become a cultural icon since his death with a nationwide posthumous campaign "Learn from Lei Feng" led by the Chinese Communist Party (CCP). His name entered daily speech and his images appeared on memorabilia. Lei has also become a source of private derision amongst the more cynical youth. Calling Liu "Lei Feng" is a form of mockery. Liu and He become two outcasts among the more flamboyant "mean girls and boys," to use the modern lexicon. The flirtatious relationship and the occasional bullying among the young dancers in Youth may be an effort by the director to imitate the trendy contemporary youth romcoms to attract younger audiences, a group otherwise with little use for a film depicting the experience of a generation coming of age during Mao's era. The sensuous display of sexual tensions and the sweet tantrums of youth are speculated by Hollywood Reporter to have been a "calculated ploy to attract the young demographic" (Tsui 2017), which is a filmgoing majority that has left Feng Xiaogang and his recent biopics and social satires behind.

A veteran commercial filmmaker responsible for establishing the lucrative Chinese New Year comedy as a genre for Lunar New Year celebration (Zhu 2010), Feng Xiaogang has transitioned from making crowd-pleasing films to making personal films more satisfying to himself and his own conscience. Part of the impetus for making Youth stems from Feng's nostalgia about his own time at an army cultural troupe during the same period. He wanted to make a film that shows that the antics of youth coming of age during the drab socialist past were just as compelling as the travails of contemporary youth. Feng spoke fondly of his own experience and how the army cultural troupe he served as a young adult "satisfied all my wishes at that time," as he puts it (Hurst 2018). The film aims to "amplify the favorable impression of the 
Cultural Troupe." The first half of the film shows the travails of pampered soldiers living a sheltered life largely unaffected by the political turmoil unfolding outside the army camp. As one critic points out, "the explicit display of sensuality and the emphasis on physicality defies China's officially sanctioned representation of the People's Liberation Army as existing well above basic human desires” (Tsui 2017).

Feng's nostalgic recast of an otherwise controversial era serves to remind audiences how the young soldiers from a more dogmatic era could be just as human as contemporary youth. As the film progresses, major political events are quickly noted only to mark the passage of time until one event: the Sino-Vietnamese war in 1979 which serves as a pivotal transition for the narrative to leap from the blissful life of army brats to the horror of war during the second half of the movie [Fig. 2]. Here the film takes a decisively less charitable tone, juxtaposing the elegant dance sequences with the exceedingly gruesome battle scenes and eventually taking us to the grim life that awaits Vietnam veterans in a newly commercialized China. As the movie takes us further into the post-socialist era, the male lead, our exemplary collectivist admired for his altruism, is shown to be outdated and cast aside in an increasingly mercantile China. Nostalgia about a purer past lingers, pitting the money-driven post-socialist now against the then seemingly blissful time in a collective cultural troupe, with war serving as disruption and the beginning of the end of an era. As Andreas Huyssen puts it, we have moved since the 1980s from being preoccupied with searching for grand futures to digging into the past. That is, we have turned our attention from "present futures" to "present pasts" (Huyssen 2003). Indeed, nostalgia in contemporary usage is primarily concerned with time, or what Stuart Tannock calls a "periodizing emotion," which perceives past as better than now (Tannock 2006). According to Tannock, time can be segmented into the "prelapsarian" epitomized by the Golden Age and such, the "lapse" - a natural catastrophe or a manmade war that disrupts or ruptures, and the "postlapsarian," which is a present that feels in some ways to be lacking, deficient or oppressive (Tannock 2006). When there is a rupture, nostalgia brings comfort and functions as an emotional refuge that shelters us from violent changes (Bronfen 1998). The "periodizing emotion" in Youth is marked by the ample repurpose of some of the old revolutionary songs in the soundtrack, which triggers mixed memories of war and sacrifice in a socialist past, intended or unintended.

2 See: Youth. All Those Years of Youth, All Those Years of “Fang Hua” (那些年的青春, 那些年 的《芳華》). Art Zip, n. d. http://www.artzip.org/youth-uk-release. Last accessed 03. 04. 2020. 


\section{Youth as Hymn to the Hero}

Youth deftly mixes songs performed diegetically as part of the onscreen stage performances by the young dancers and singers and non-diegetically, as theme music, revolutionary hymns popular in the 1960s-1970s, which, as one reviewer commented, brought back the memory of her youth: "It makes me feel nostalgic" (Weerasekara 2018). All of the songs in Youth have their origins in the Mao era, when personal sacrifices at the service of the nation were glorified. Many come from old revolutionary classics, the films that were popular in the 1960s. The soundtrack resonated widely among the generation coming of age during Mao's era. So much so that one Chinese fan set up an online repository to list the titles and lyrics of all the songs from the film and their origins from classic war films (Xiao 2018). The songs have been shared widely on Chinese social media and Youtube.

One song, Hymn to the Hero (英雄赞歌) originated in a 1964 film about Chinese People's Volunteer Army soldiers fighting against the US and its allies during the Korea War (1950-1953), Heroic Sons and Daughters (武兆, Wu Zhaoti), which is an adaptation of Reunion, a novella published in 1961 in a high-brow Chinese literary magazine Shanghai Literature by the renowned Chinese writer Ba Jin. Best known for his novel The Family, Ba Jin is one of the most well-known and widely read Chinese authors of the $20^{\text {th }}$ century. Reunion, a little-known work, resulted from a North Korea tour he joined as part of a literary group dispatched by China's National Cultural Workers' Association during the height of the Korean war in early 1952 (Ying 2019). The resulting novella Reunion depicts how the war engulfs the lives of five siblings in a family, leading to their separation and eventual reunion on the battlefield. Xia Yan, a playwright known for his pro-CCP film activities during the Republic era and later the deputy head of the Chinese Culture Ministry assigned to Changchun Film Studio, one of the earliest film studios under the CCP, to adapt the story into a movie. Wu Zhaoti, born in Pittsburgh to an overseas Chinese intellectual family ${ }^{3}$ and later known for directing one of the eight model opera films, ${ }^{4}$ Shajiabang (1971), was tapped to direct the film. The finished film focused on one sibling in particular, the now legendary martyr, who sprinted into the enemy's command center holding a Bangalore torpedo, killing the enemies, and himself in the process. The death of the hero led to the unexpected reunion on the battlefield of his father

3 See: Wu Zhaoti [武兆堤]. Bai Ke Bai Du. https://baike.baidu.com/item/武兆堤. Last accessed 03. 04. 2020.

4 The eight model operas are stage plays orchestrated by Jiang Qing, the wife of Chairman Mao Zedong during the Cultural Revolution (1966-1976). Revolutionary in both theme and musical features in comparison to the traditional Chinese operas, many of them were adapted to film. 
and sister. The sister, a singer at the Army Cultural Troupe then performs the song, Hymn to the Hero, paying tribute to her brother and other fallen heroes. The song was written by the poet Gong Mu (公木) known for writing in 1939 the lyrics of the Military Anthem of the Eighth Route Army, a CCP army branch during the Republic era. The song was anointed in 1988 as the anthem of the People's Liberation Army. Newly exonerated from his earlier conviction as a rightist during the anti-rightist campaign, ${ }^{5}$ Gong was reluctant to accept the overture of writing lyrics for the film for fear of any potential political fallout but eventually took up the assignment. ${ }^{6} \mathrm{Liu}$ Chi (刘炽), a Chinese composer with quite a few popular socialist songs under his belt was chosen to compose the song. The final melody reportedly drew inspiration from Mongolian folk songs Liu was exposed to during his field days collecting folk songs in Inner Mongolia (Ti 2019).

Both the film and the theme song came out to great fanfare at a time when Hollywood films were banned and the only few films available were socialist propaganda pieces. When the Cultural Revolution started with a vengeance in 1966, Ba Jin was denounced and his novella Reunion was accused of promoting pacifism and exaggerating the horror of the war by deliberately sending the hero to death (Ba 2005). ${ }^{7}$ The film survived unscathed, though the subtitles "adapted from Ba Jin's novella" was removed (Fa 2003). ${ }^{8}$ Both the film ${ }^{9}$ and its theme song have now become part of the revered "red classics," this latter being performed repeatedly by wellknown Chinese singers including Peng Liyuan, an army soprano with soaring voice and now China's first lady. Peng's popular 2007 album, My Soldier Brothers included this song. In Youth, the song appears during the second part of the movie, when Liu, the wounded male lead stays alone in the battlefield after ordering his remaining team to evacuate and take the fallen soldiers out. As the truck carrying his comrades pulls away, we see Liu, played by the painfully handsome dancer turned actor and heartthrob Huang Xuan standing alone in the war-ravaged roadside. The film then cuts to a tracking shot of Liu leaning against an abandoned military vehicle. The

The Anti-Rightist Campaign was a political campaign from 1957 to 1959 to purge alleged "Rightists" within the Communist Party of China (CPC) and abroad. The definition of rightists officially referred to those intellectuals who appeared to favour capitalism and were against collectivization. Launched by Chairman Mao, the campaign led to the political persecution of at least 550,000 people.

6 See: Ying Xiong Zan Ge [《英雄赞歌》]. Zhong Hua Gong Shi Wang. http://gong4.zupu.cn/ wenhua/317761.html. Last accessed 03. 04. 2020.

7 “渲染战争恐怖、有意让英雄死亡, 鼓吹和平主义”: https://web.archive.org/web/20060920023943/ http://book.sina.com.cn/nzt/his/suixianglu/78.shtml. Last accessed 03. 04. 2020.

8 Undated original content from law-thinker.com, archived at https://archive.ph/20041212182401/ http://law-thinker.com/show.asp?id=1692. Last accessed 03. 04. 2020.

9 Hymns to Hero remains the most well-known film about the Korean War in China. 
camera closes on him and we see his expressionless eyes staring into the distance as if in a trance. We hear a voiceover accompanied by melancholic melody speculating, in an ironic tone, his mental state. "Perhaps the deputy instructor was right. He didn’t want to live. He yearned to be a martyr. Only through sacrifice would his ordinary life become a hero's tale, and his heroic story would grow and spread and travel far. Maybe it would be turned into a song with lyrics and a tune in the songbook of a female singer. A singer named Lin Dingding, who, in the end, would have to sing for him. And every time she sang, she would have to remember him." The ironic voiceover defuses the otherwise melodramatic undertone of the sequence, and is a quintessential touch of Feng Xiaogang, whose signature genre, the lunar New Year comedy is known for its biting satire (Zhu 2007). And the female singer in question is Liu's love interest, who had spurned his overture earlier in the movie.

\section{Youth as a Love and War Story}

Roll back in time, earlier in the film, the sound of a soft Taiwanese ballad sung by the Taiwanese pop icon Teresa Deng stirs up passions in our otherwise upright communist hero and leads him to a misguided confession of love for a wrong girl, not the leading lady we root for, which results in an awkward yet consequential embrace. [Fig. 3.] While alone in a room with his love interest, who is a lead singer in the art troupe, our hero expresses his admiration for her. She is flirtatious but non-committal. As she is leaving, he stops her at the door and pulls her close for a tight embrace while whispering to her ear that he loves her. This mistimed moment is observed by two fellow troupe members who happen to be walking by. One member snaps and says in an exaggerated tone that earlier the Commissar had said that "rot in an army begins with rot in behaviour." Embarrassed and confused, the girl pushes Liu aside and runs off.

This awkward moment is a poignant reminder of a rigid Mao era, when revolution took place in one's bedroom, and personal affection and intimacy were forbidden, or at least not allowed to show publicly, including in films. The voyeuristic Chinese audiences in turn flocked to Eastern European films, the only imports allowed, to catch glimpses of kisses and embraces. Romanian and Albanian films in particular, with their ample hugging and kissing were popular hits, serving as a rite of passage for young lovers on clandestine dates. Soviet films, with their occasional scenes of intimacy also drew Chinese fans. As recounted by Wu Haohu (吴鹤沪), a film projectionist who did mobile screenings for PLA troupes, the soldiers loved Lenin in 1918 (Mikhail Romm 1939), a Soviet film depicting the failed assassination of 
Lenin, partly for the ritual of kisses and embraces when characters greeted each other (Ni 2013). The projectionists were instructed to block inappropriate scenes while screening foreign imports. In the case of Lenin in 1918, there were two scenes that were deemed objectionable, one showcasing a Swan Lake performance as an assassination was being plotted at a theatre, the other depicting the night when Lenin settles into the home of his protégé Vasili to rest. In the first scene, the dancers with their short skirts exposing bare legs were thought to be indecent. In the second scene, Lenin settles into Vasili's living room and drifts off as the relieved Vasili and wife look on. The wife then leans back and onto her husband's shoulder, which leads to sexually charged hugs and kisses. Wu had been diligently blocking the two scenes whenever they came up, leaving the music and the dialogue to "speak" for a black screen. He relented during one screening, letting parts of the film remain visible through the gaps between his fingers. Audiences perked up instantly as he recounted, and no harm was done.

In Youth, the innocent embrace leads to the girl's report to the political commissar, which leads to a sinister interrogation scene where our model soldier is coerced into confessing to sexual harassment. As punishment for his refusal to acknowledge his alleged sexual transgression, Liu is assigned to a Sino-Vietnam border outpost and eventually sent to the battlefield. During one battle, Liu's team is ambushed and suffers casualties. Liu himself is wounded. As he watches the truck pull away and take his comrades to safety, the song Hymns to the Hero fades in, together with the voiceover narration about how he wishes for the girl to sing for him. The camera then takes us to the diegetic performance scene where the girl to whom he declared his love earlier is performing the song to a group of soldiers in the field. As she sings, the subtitle shows the English translation of the lyrics:

"Smoke billows from the beacon fire.

I sing of a hero.

The rings of mountains bend their ears.

In the blue sky, thunder beats a golden drum.

The ocean churns with waves singing in harmony.

The people's warriors drive out the predators,

Laying down their lives to protect peace.

Why is our battle flag as pretty as a picture?

The blood of heroes has stained it red."

Played as the wounded hero's death wish and his revenge fantasy as he hallucinates about the posthumous devotion of the girl who earlier spurned his overtures, the Hymns to the Hero song turns eerily haunting. Though the original song is written 
to pay tribute to heroes in a different war with a different cast of young lives, the message is the same: dying for one's country is heroic and glorious, whether the Korean War, or the Sino-Vietnamese War, which is a subject rarely touched upon.

Youth is the first Chinese film that directly touches upon the subject of the SinoVietnamese War. China went to war with Vietnam in 1979, after Deng Xiaoping pushed to punish Vietnam for occupying Cambodia and overthrowing the brutal Khmer Rouge regime, which was an ally of China. Deng reportedly sought a quick war yet the Chinese army's incursions into Vietnam did not go as planned. China and Vietnam each suffered heavy casualties. Leaks from Chinese military sources indicate that China suffered 6,954 deaths and lost 3.45 billion yuan in overhead, delaying the completion of its 1979-80 economic reform plan. Youth deftly wades into the Sino-Vietnamese War by throwing its main characters into the horrific battlefield without explaining what the soldiers were fighting for, or against, which rendered the war and its attendant human sacrifice utterly meaningless and cruel. Youth met resistance from the censors and its scheduled colossal rollout across China was halted amidst the Chinese Communist Party's preparation for the national congress in October 2017, a political event staged every five years (Choi 2017). It turns out that veterans of the Sino-Vietnamese War, a group featured in Youth, had previously protested at the Congress, seeking better compensation and treatment. Some speculated that officials delayed the film's release in fear of triggering a new round of protests at the 2017 Party Congress.

There are other potentially objectionable scenes in Youth, particularly the gruesome infirmary and brutal battle scenes. In a remarkably fluid five-minute and 30-second-long take in the film, the camera sweeps around the chaotic battlefield, darts over explosive tanks, finally settling on desperate soldiers trying to save one of their own. An explosion wounds Liu and eventually leads to the amputation of one of his arms. Feng reportedly wanted "to make audiences see the cruelty and terror of war," which might have contributed to the film's delayed release (Buckley 2017; sina.com.cn 2017). To make the matter worse, Youth depicts the hardships veterans endured after the war. In one key scene depicting the aftermath of the war, our leading man, now a disabled war veteran is being manhandled by thugs from the notorious local Public Orders Bureau (POB), a controversial civilian organization set up to assist the police in patrolling the community. POB is notorious for harassing people for minor offenses with steep fines, and also for blatant extortion. When Liu tries to reclaim a vehicle that was confiscated for a minor traffic violation, a vehicle he relies on as a delivery man to pay his bills, the POB handlers literarily "threw him out" after a physical scuffle. 
Youth was eventually released on December 15, albeit with a much smaller rollout. The version eventually screened in public in China is said to have been 11-12 minutes shorter than the one that premiered at the Toronto Film Festival on September 28, 2017 (Weerasekara 2018). During a screening at the Pingyao Film Festival in late October 2017, Feng said that the cuts were an effort to "sharpen the film's rhythm" and draw younger audiences (Weerasekara 2017). Despite the cuts, which reportedly include scenes that capture human cruelty living in the Mao era, when the film was released, China's Police Departments were reported to have monitored its screenings. An unnamed theatre manager reportedly revealed that local police departments in several Chinese cities sent police officers to some screenings of Youth in order to monitor audiences' reaction to certain scenes in the film. ${ }^{10}$

\section{Youth as Revolutionary Songs and Cultural Memories}

Youth nonetheless became a popular hit upon release, eliciting both tears and chatter about China's collective and individual memories of a bygone era. The film raked in $\$ 48$ million during its opening weekend, nearly 30\% higher than the figure for Coco (Lee Unkrich and Adrian Molina 2017), ${ }^{11}$ the 3D animation sensation (Weerasekara 2018). Audiences spoke fondly of the film, particularly its appropriation of popular songs from a different era. "The 1970s' propaganda music in the soundtrack reminds me of my youth and of what our families went through," said a 53-year-old security guard to a reporter. "It makes me feel nostalgic." (Week in China 2018.) My own interviews with Chinese audiences confirm that scenes depicting the more innocent and cheerful time at the cultural troupe in the first half of the film trigger fond memories of a past seen as less stressful and more innocent. Nostalgia for a collective socialist past when society was perceived to be less mercantile is palpable. But not all memories are associated with nostalgia. The darker moments in Youth easily trigger nostophobia, the fear of a bygone era. As one Chinese viewer reflects on the interrogation scene when our hero is forced to detail his sexual transgression, "the false allegations in the film are reminiscent of tactics used during the Cultural Revolution to destroy someone's career” (Weerasekara 2018). The viewer reflected further that "the film is full of such references to rotten things that happened in that era" (Weerasekara 2018). It is clear that while revolutionary songs and dance numbers, and happy lives of innocent youth in the first half of the film bring back

10 See: Headlines from China: China's Police Departments Monitor Screenings of 'Youth.' 2017. China Film Insider, December 15, 2017. http://chinafilminsider.com/headlines-from-chinachinas-police-departments-monitor-screenings-of-youth/. Last accessed 03. 04. 2020.

Coco, incidentally, is also a film about nostalgia. 
nostalgia, the darker sequences in the film trigger negative memories, or the fear of returning to a past that is associated with negative emotions and experiences (Baake-Hansen 2015).

As the story develops further, the female lead, who is secretly in love with Liu, is also dismissed from the dance troupe after she passively resists her dance assignments as a way to protest Liu's dismissal. As punishment, she is sent to a warravaged casualty ward where she undergoes a traumatic rite of passage as a young army nurse attending to disfigured and dying soldiers with both disorientation and anguish. She yearns for Liu but lives in fear of seeing him at her infirmary where only the severely wounded are sent. She eventually suffers a nervous breakdown and is sent to a mental hospital. The version of the film publicly screened in China omits the scene when her nervous breakdown occurs. The original film shows - in a typical ironic Feng Xiaogang fashion - that she loses her mind at the moment she is given a medal of honour at an award ceremony to recognize her contribution and extol the sacrifices of the soldiers who died and suffered for their country.

The end of the film takes us to a gritty epilogue set in the 1990s, when the state controlled market economy took hold in China, leaving the less fortunate - including the two main characters - to fend for themselves. Here the film takes a decisively rueful turn, with its theme song, Sumptuous Flower playing over the film's last montage sequence when the two main characters reunite years later, and she finally confesses her love for him after all the lost time [Fig. 4]. As he leans over to wrap her in his arms, the theme song swells in, accompanied by a voiceover narration that tells us that ten years from now, the two will remain friends and will look after each other. The theme song continues as the camera pulls back from the two old friends sitting on a bench outside a train station and the closing credits roll. It is a song with a piercingly melancholic tune and hauntingly metaphoric lyrics that gets me personally every time. The song is yet another repurposed revolutionary tune, this time from a popular 1979 film, Little Flowers (张铮, Zhang Zheng, 1979), a patriotic film about two young women with no knowledge of their interlaced family history who fight side by side for the Chinese Communist party during China's Civil War. Similar to Hymn to the Hero, which was written for the Korean war, Little Flowers in its original version features a different war. Composed by a veteran Shanghainese composer, it plays over the scene of a female solider climbing up long and steep stairs with bloody feet and knees carrying a wounded fellow soldier to safety. The song highlights heroism and is uplifting in its original version. When used in Youth, it is elegiac, the mourning of a youth that is prematurely annihilated. The lyrics of Sumptuous Flowers become a metaphor for a past that is both innocent and traumatic: 
"There is a beautiful flower in the world

The flower is youth, wonderfully fragrant

Strong and unyielding it blooms

And its petals are stained with blood

Sumptuous flower

Its sweet aroma all along the road up the mountain cliffs

In the world there is a heroic flower

The flower is growing youth

The flower bears its loved ones up the mountainside

To stand tall and proud and greet the sunlit clouds

Sumptuous flowers

Its sweet aroma all along the road up the mountains."

The pathos triggered by the song is excruciating, at least to me, as I mourn the loss of a generation, and indeed the waste of an entire nation being swept up by the brutality of wars and political violence: historical traumas that apply not only to China. A life sacrificed is a life decimated, no matter when, where, and for what purposes. Judging by the conversations I had with some audiences, the cultural memories the song conjures up have stirred up both tenderness and sorrow among the generation of Chinese viewers whose lives were so thoroughly devoured by years of relentless political campaigns. In a black humour style typical of Feng's signature satire, Youth is punctuated with the subversive repurposing of old revolutionary songs that wax lyrical about sacrifices and wars of different eras. Accompanied by the same melodies and lyrics, the sacrifices and wars become inter-changeable and thus lose their initial sacredness and glory. The fact that one song can be applied to all wars puts the absurdity of war and politics on full display. "We believed in the call of duty and the fight for our country. We were proud of our sacrifices. But what's the point of all the sacrifices looking back now" is what one Vietnam veteran said to me with resigned sorrow while reflecting on how the songs in Youth resonate. By triggering among certain viewers a complex set of memory mixing yearning and mourning, the film's soundscape re-summons the experience of a past time and place as it sets the tone of nostalgia together with nostophobia for our summation. Youth's soundscape raises intriguing questions about the impact of the codification and memorialization of certain historical events utilizing patriotic anthems and tunes, memorial hymns, and even noises such as the sound of warfare. If, as Walter Benjamin claims, history breaks down into images, history can certainly persist in memory in relation to sounds that are either connected to or disconnected from the past events. 


\section{Youth as Nostalgia and Nostophobia}

Youth reflects and enlivens the director's ambivalent personal memory of China from the late 1970s to the 1990s. Viewers' emotional reactions to the film are linked to their own experiences as part of the collective social memory, which is conditioned by the zeitgeist of the Mao era. The revolutionary aesthetic reflected in the theme songs of classic revolutionary films forms the affective dimension of that era. The social zeitgeist and the aesthetic experience of that zeitgeist form what Raymond Williams calls "structures of feeling” (Williams 1977). This concept tackles the issue of nostalgia from a cultural studies perspective. It tries to capture "a particular quality of social experience and relationship, historically distinct from other particular qualities, which gives the sense of a generation or a period" (Williams $1977,131)$. In other words, it tries to capture "the elusive stratum of reality" that is “evanescent in its manifestations" (Sharma and Tygstrup 2015, 1). Williams suggests that we complement the analysis of the social and material infrastructure of reality with a third layer, that of affective infrastructure. Our interpretative horizon is very much linked to a particular structure of feeling, and to the interaction between our unique experiences and a larger historical condition.

While western Marxism has placed more emphasis on economy and philosophy than on culture at large, Williams calls our attention towards the historical production of space, the social and cultural life/world, the "thick" anthropological description of historical reality, and the physiological sensations including feelings and emotions, moods and drives, propensities and longings, dreams and visions, and also rage, love, hate, lust, disgust, pride, shame, elation, and so on. "Feeling" is more fluid than fixed "world-views" or "ideologies," and more in line with meanings and values as actively lived and felt. Nostalgia and nostophobia are part of this emotional experience under the larger umbrella of "structures of feeling." As Devika Sharma and Frederik Tygstrup articulate in the introduction to their book, Structures of Feeling: Affectivity and the Study of Culture, Williams's approach examines how experience is articulated in a close and complex interaction between humans and their environments, how it plays out in a particular spatial framework, and how it is inextricably invested in and dependent on social relations between humans, and between humans and social institutions (Sharma and Tygstrup 2015). This approach directs us to the multifarious fabric of everyday life, and to the ways in which culture is continuously reproduced in still new dimensions. For Williams, affective infrastructure regulates our predisposition and modes of presence as well as our participation in social situations. 
Youth has divided critics, with some panning it as a vacuous love letter to a cushy adolescence, and others praising it for its gritty depiction of war. Some dislike the film for its sentimentality and charge it with historical revisionism. Some charge the film with failing to take a critical stand against an art troupe that instills patriotism in fellow soldiers, and disapprove of its celebration of spectacular renditions of military songs and dance numbers. This criticism essentially equates nostalgia with romanticizing a brutal past that is supposed to be unconditionally repudiated. The criticism fails to account for the complexity of our individual and collective memories. As structures of feeling, nostalgia and nostophobia are modes of memory that are closely connected with but also different from each other. Svetlana Boym makes a distinction between restorative nostalgia and reflective nostalgia (Boym 2011). As Boym puts it, "restorative nostalgia manifests itself in total reconstructions of monuments of the past, while reflective nostalgia lingers on ruins, the patina of time and history, in the dreams of another place and another time" (Boym 2001, 49-50). Conceived in this way, the longing in nostalgia does not preclude critical thinking, and fond memories do not absolve one from critical reflection.

Both nostalgia and nostophobia share a strong connection to the lost home/ time. A nostalgically remembered chronotope can be hostile, cold, and dark, which generates disgust and repulsion. Yet it is still about nostos, i.e., home. It can be a lost homeland devoid of the usual utopian and romantic images. It could be a dystopian chronotope that elicits fear and loathing. In his work comparing Joseph Roth - an Austrian journalist and novelist best known for his family saga Radetzky March (1932) about the decline and fall of the Habsburg empire - and Herta Müller, the Romanian born German novelist who won the Nobel Prize in Literature for her work depicting the effects of violence, cruelty and terror under the Socialist Republic of Romania, Martin Baake-Hansen argues that nostalgia transforms flaws and weaknesses into virtues and merits in Joseph Roth's romantic depiction of a lost empire, while nostophobia highlights them in the unflinching works of Herta Müller (Baake-Hansen 2015). Both emotions co-exist in Youth, with the repurposed old revolutionary songs evoking and bridging these pasts. The theme song for Youth, Sumptuous Flowers strikes a simultaneous chord of nostalgia and nostophobia in viewers, including me, stirring up the overwhelming sensation of yearning for a more innocent imaginary past and the mourning of the loss of that innocence, a sensation so acute that it paralyses. The past we yearn for is connected to a particular period in our lives, what we casually and at times dismissively call youth. In a sense, memory is never pure nor absolute. As Martin Baake-Hansen $(2015,122)$ puts it, "nostalgia cleans up the past, while nostophobia displays its dirt," and both are two 
sides of the same coin. Expressed in the stylistic approach of a film, emotional tone conditions how audiences receive and perceive the work. Youth's intense focus on the rise and fall of individuals against the sweeping panorama of a nation in transformation elicits both compassion and repulsion, nostalgia and nostophobia. The film triggers in us the memory of a simpler time with moments of blissfulness and innocence but also of profound sadness for how political and national events can lay waste to the personal and the individual. Youth elicits both fond memories and critical reflection.

\section{References}

Anspach, Carolyn Kiser. 1934. Medical Dissertation on Nostalgia by Johannes Hofer, 1688. Bulletin of the Institute of the History of Medicine vol. 2, no. 6: 376-391.

Ba, Jin. 2005. Instill and Promote (5th Exploration) (1) [灌输和宣传 (探索之五 (1)]. Sina, October 17, 2005. https://web.archive.org/web/20060920023943/http:// book.sina.com.cn/nzt/his/suixianglu/78.shtml. Last accessed 03. 04. 2020.

Baake-Hansen, Martin. 2015. Nostalgia and Nostophobia: Emotional Memory in Joseph Roth and Herta Müller. In Structures of Feeling: Affectivity and the Study of Culture, eds. Devika Sharma and Frederik Tygstrup, 116-123. Berlin: Walter de Gruyter.

Boym, Svetlana. 2011. The Future of Nostalgia. New York: Basic Books.

Bronfen, Elisabeth. 1998. The Knotted Subject: Hysteria and its Discontents. Princeton: Princeton University Press.

Buckley, Chris. 2017. Touching on History, a Chinese Film May Have Been Burned by It. New York Times, September 25, 2017. https://www.nytimes.com/2017/09/25/ world/asia/china-movie-youth.html. Last accessed 03. 04. 2020.

Chi-yuk, Choi. 2017. China Pulls Vietnam Border War Movie from Cinema Holiday Line-up at Last Minute. South China Morning Post, September 24, 2017. https:// www.scmp.com/news/china/policies-politics/article/2112621/china-pullsvietnam-border-war-movie-cinema-holiday. Last accessed 03. 04. 2020.

Hirsch, Marianne. 1997. Family Frames: Photography, Narrative, and Postmemory. Cambridge: Harvard University Press.

Hurst, Matthew. 2018. How Feng Xiaogang's “Youth” Navigated Censorship and Delays to Find a Global Audience. RADII, June 4, 2018. https://radiichina.com/ how-feng-xiaogangs-youth-navigated-censorship-and-delays-to-find-a-globalaudience/. Last accessed 03. 04. 2020. 
Huyssen, Andreas. 2003. Present Pasts: Urban Palimpsests and the Politics of Memory. Stanford: Stanford University Press.

Jenkins, Mark. 2017. 'Youth:' A Controversial Chinese Melodrama about a Military Arts Troupe. Washington Post, December 8, 2017. https://www.washingtonpost. com/goingoutguide/movies/youth-a-controversial-chinese-melodrama-about-amilitary-arts-troupe/2017/12/08/d95b8c28-daca-11e7-a841-2066faf731ef_story. html. Last accessed 03. 04. 2020.

Ni Er [聂耳]. 2013. Peeking through Fingers for Lenin in 1918 [指缝间流出的(列 宁在一九一八》]. Wen Xue City. April 27, 2013. https://bbs.wenxuecity.com/ xianshibian/526995.html. Last accessed 03. 04. 2020.

Tannock, Stuart. 2006. Nostalgia Critique. Journal of Cultural Studies vol. 9, no. 3: 453-464.

Ti Qin Yue Pu [提琴乐谱]. 2019. Violin Score of Ying Xiong Zan Ge (The Song in Ying Xiong $\mathrm{Er} \mathrm{Nu}$ ) [英雄赞歌 (电影《英雄儿女》插曲) 小提琴谱].

Tsui, Clarence. 2017. 'Youth' ('Fang Hua'): Film Review. Hollywood Reporter, March 11, 2017. https://www.hollywoodreporter.com/review/youth-fang-huafilm-review-1053214. Last accessed 03. 04. 2020.

Weerasekara, Poornima. 2018. 'Youth:' Feng Xiaogang's Paean to Nostalgia. China Film Insider, January 1, 2018. http://chinafilminsider.com/youth-feng-xiaogangspaean-to-nostalgia/. Last accessed 03. 04. 2020.

Williams, Raymond. 1977. Marxism and Literature. London and New York: Oxford University Press.

Zhu, Ying. 2007. Feng Xiaogang and Chinese New Year Film. Asian Cinema vol. 18, no. 1: 43-64.

Zhu, Ying. 2010. New Year Film as Chinese Blockbuster: From Feng Xiaogang's Contemporary Urban Comedy to Zhang Yimou's Period Drama. In Art, Politics, and Commerce in Chinese Cinema, eds. Ying Zhu and Stanley Rosen, 195-208. Hong Kong: Hong Kong University Press. 


\section{List of Figures}

Figure 1. The two leading characters in Feng Xiaogang's Youth (2017).



Figure 2. The hero's blank stare in the Vietnam War.

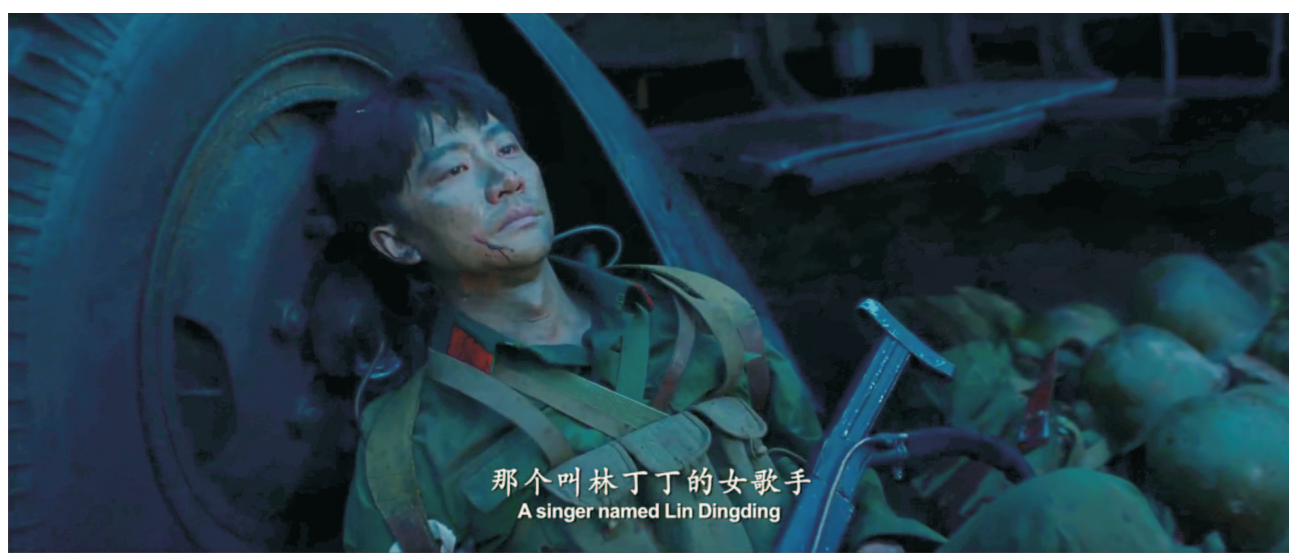


Figure 3. The mistimed embrace of the characters.

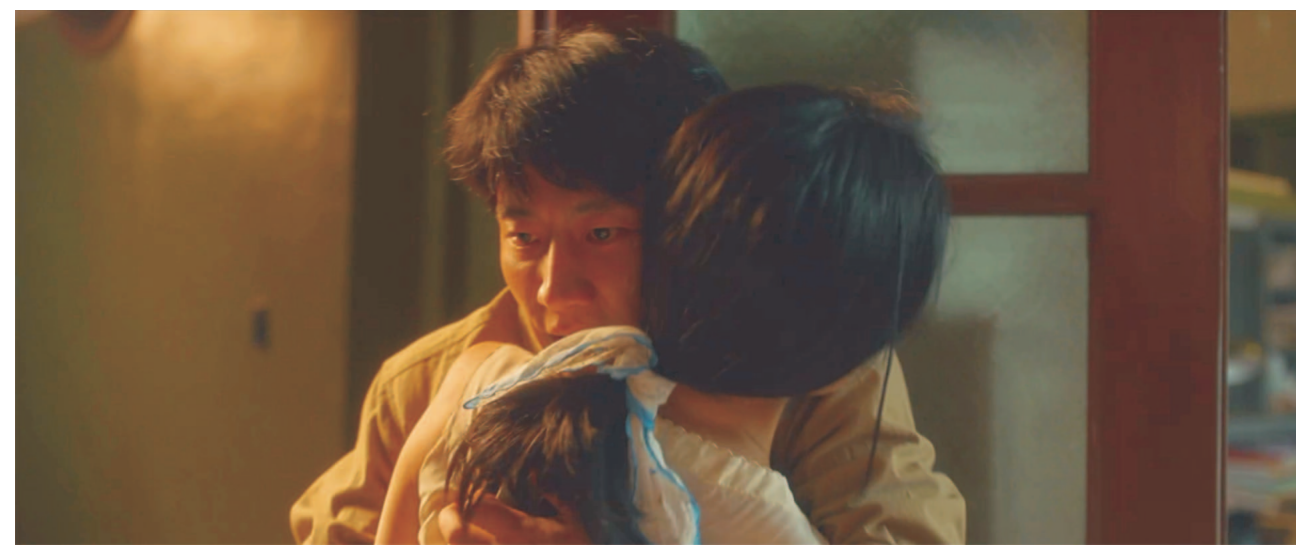

Figure 4. The reunion of the main characters.

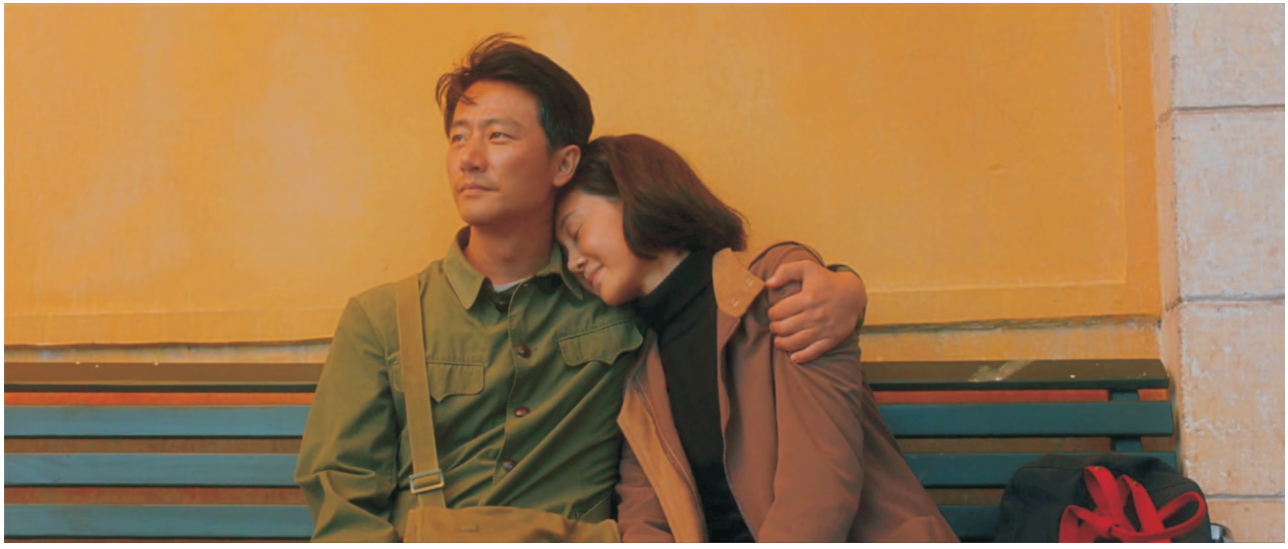

